Teosofia: Indonesian Journal of Islamic Mysticism, Vol. 10, No. 2, 2021, pp. 177-192

e-ISSN: 2540-8186; p-ISSN: 2302-8017

DOI: $10.21580 /$ tos.v10i2.9670

\title{
ABU NU'AYM AL-IṢFAHĀNĪ (d. 430/1038): Conflicting Opinions
}

\author{
Meis Al-Kaisi \\ American University of Sharjah \\ malkaisi@aus.edu
}

Article History: Received: 8 October 2021; Accepted: 6 December 2021; Published: 22 December 2021

\begin{abstract}
:
Abu Nu'aym al-Ișfahānī (d. 430/1038) is a renowned figure with a glorious reputation. He is known as a hadith traditionist, historiographer, advocate of Sufism, and author of many works, the most celebrated of which is Hilyat al-awliyā' wa-țabaqā t al-așfiyā'. Nonetheless, despite his glorious reputation, some scholars have criticized him and his renowned Hilya. Scholarship, in its turn, both classical and modern, has served Abu $\mathrm{Nu}$ 'aym no justice. Classical Arabic literature presents some information about his life and works in scattered short biographical entries. Modern scholarship has even less to offer in this regard. None of the existent sources presents a single biography that delivers a precise examination of $\mathrm{Abu} \mathrm{Nu}$ aym's status treating the opinions of both supporters and critics. This paper evaluates the conflicting opinions. It puts the puzzle pieces together to deliver a focused study of particular biographical details in Abu $N u$ 'aym's life that examine the praise he has received from his proponents as well as the criticism from his opponents. This paper is the result of a project that assessed every available biographical entry on $\mathrm{Abu} N \mathrm{Nu}^{\prime}$ aym in both classical and modern literature to determine the different opinions on the scholar concerned. It delivers a list of all the literature that has a biographical mention of $\mathrm{Abu} \mathrm{Nu}$ aym and that which has been examined for this study. This paper reveals that information about $\mathrm{Abu} \mathrm{Nu}$ aym in primarily classical sources proved that criticism may be biased and religiopolitically driven.
\end{abstract}

Keywords: Abu Nu'aym al-Ișfahānī; biography; criticism; Sufism; țabaqāt

\section{A. Introduction}

$\mathrm{I}$

$\mathrm{n}$ the medieval biographical dictionaries and in the Sufi handbooks, where one would normally expect to find substantial records about relevant figures, little is mentioned about the life and the activities of the hadith traditionist (muhaddith) Abu Nu'aym al-Ișfahānī. Nonetheless, the little scattered information that has been reported is of great importance once collected and put together as it then offers a deeper insight into his life.

Distinguishing the relevant sources and pointing out the key ones is a prerequisite for utilizing the provided information efficiently. Thus, the sources that contain a biographical record of $\mathrm{Abu} \mathrm{Nu}$ aym are herein divided into three categories: 
(1) Classical, (2) Post-Classical, and (3) Modern. This division is based on specific periods, during which the relevant sources were written.

The 'Classical' period is considered to be between the $6^{\text {th }} / 12^{\text {th }}$ and $8^{\text {th }} / 14^{\text {th }}$ centuries. The works that fall into this category are:

- Al-Bidāya wa-l-nihā ya by Ibn Kathīr (d. 774/1373). ${ }^{1}$

- Al-'Ibar fi khabar man ghabar; Mizān al-i'tidāl fi naqd al-rijāl; Siyar a'lām al-nubalā'; and Tadhkirat al-huffãz by Shams al-Dīn Muhammad al-Dhahabī (d. 748/1348). ${ }^{2}$

- Mu'jam al-buldān by Yāqūt al-Hamawī (d. 626/1229). ${ }^{3}$

- Al-Muntazam fi tawan̄kh al-mulūk wa-l-umam by Ibn al-Jawzī (d. 597/1200). ${ }^{4}$

- Tabaqāt al-shāfíiyya al-kubrā by Tāj al-Dīn Abd al-Wahhāb al-Subkī (d. 771/1369). ${ }^{5}$

- Tabȳn kadhib al-muftañ fi-ma nusiba ilā al-imām Abì al-Hasan al-Ash an̄̄ by Ibn 'Asākir (d. 571/1176). ${ }^{6}$

- Wafayāt al-a' yān by Ibn Khallikān (d. 681/1293). ${ }^{7}$

The 'Post-Classical' period is considered to be between the $9^{\text {th }} / 15^{\text {th }}$ and $11^{\text {th }} / 17^{\text {th }}$ centuries. The works that fall into this category are:

- $\quad$ Lisān al-mīzā $n$ by Ibn Hajar al- ${ }^{\circ}$ Asqalānī (d. 852/1449). ${ }^{8}$

- Tabaqā al-ḥuffạz by Jalāl al-Dīn al-Suyūṭi (d. 911/1505). ${ }^{9}$

- Al-T abaqā t al-kubrā by Abd al-Wahhāb al-Sha arānī (d. 925/1519). ${ }^{10}$

- Shadharāt al-dhahab fi akhbār man dhahab by Ibn al- 'Imād (d. 1089/1679). ${ }^{11}$

Ismail Ibn Kathīr, Al-Bidāya Wa-l-Nihāya, $3^{\text {rd }}$ ed. (Beirut: Dār al-Kutub al- 'Ilmiyya, 1986).

2 Muhammad Al-Dhahabī, Tadhkirat Al-Huffāz, 2nd ed. (Hyderabad: Dā'irat al-Ma`ārif al-Niz̄āmiyya, 1915); Muhammad Al-Dhahab̄̄, Al-'Ibar F̄̄ Khabar Man Ghabar, ed. Fu'ād Sayyid (Kuwait: alTurāth al- 'Arabī, 1960); Muhammad Al-Dhahabī, Mizān Al-I'tidāl F̄̄ Naqd Al-Rijāl, ed. Ali AlBajaw̄̄ (Cairo: Dār Ihyyā' al-Kutub al-'Arabiyya, 1963); Muhammad Al-Dhahab̄i, Siyar A'lām AlNubalā' (Beirut: Mu'assassat al-Risāla, 1981).

3 Yāqūt Al-Hamawī, Mu 'jam Al-Buldān, ed. Ferdinand Wüstenfeld (Leipzig: F. A. Brockhause, 1866).

4 Abd al-Rahman Ibn Al-Jawzī, Al-Muntazam F̄̄ Tawarīkh Al-Mulūk Wa-l-Umam (Beirut: Dār al-Fikr, 1995).

5 Abd al-Wahhāb Al-Subkī, Ṭabaqāt Al-Shāfi ‘uyya Al-Kubrāa, ed. Mahmud Al-Ṭanaḥ̄ and Abd al-Fattah Al-Hulw (Cairo: al-Halabī, 1964).

6 Ali ibn 'Asākir, Tabȳ̄n Kadhib Al-Muftarī F̄̄-Ma Nusiba Ilā Al-Imām Ab̄̄ Al-Hasan Al-Ash'ar̄̄ (Damascus: Matba'at al-Tawthīq, 1928).

7 Ahmad Ibn Khallikān, Wafayāt Al-A yānn: Ibn Khallikan's Biographical Dictionary, trans. Bn Mac Guckin de Slane (Paris: Benjamin Dupart, 1842); Ahmad Ibn Khallikān, Wafayāt Al-A yāan: Biographies of Illustrious Men, ed. Iḥsān Abbas (Beirut: Dār al-Thaqāfa, 1968).

8 Ibn Ḥajar Al- 'Asqalānī, Lisān Al-Mīzān, ed. Adil Abd al-Mawjūd and Ali Mu awwaḍ (Beirut: Dār alKutub al- 'Ilmiyya, 1996).

9 Jalāl al-Dīn Al-Suyūṭi, Tabaqāt Al-Huffāz, ed. Ali Umar (Cairo: Maktabat Wahba, 1973).

10 Abd al-Wahhāb Al-Sha arān̄̄, Al-Ṭabaqāt Al-Kubrā (Cairo: Maktabat wa-Maṭba at Muhammad Ali Șubayḥ wa-Awlādih, 1897).

11 Abd al-Hayy Ibn Al- 'Imād, Shadharāt Al-Dhahab F̄̄ Akhbār Man Dhahab, ed. Mahmud Al-Arna'ūt (Damascus: Dār Ibn Kathīr, n.d.). 
The remaining works constitute the 'Modern' category, which covers works written in the $14^{\text {th }} / 20^{\text {th }}$ century and beyond. These are:

- Abu Nu'aym, hayā tuhu wa-kitā buhu al-Hilya by Muhammad al-Ṣabbāgh. ${ }^{12}$

- Abu Nu'aym's Sources for Hilyat al-awliyā', Sufi and Traditionist by Christopher Melchert. ${ }^{13}$

- $\quad$ Al- $A^{\prime}$ lā $m$ by Khayr al-Dīn al-Ziriklī (d. 1395/1976). ${ }^{14}$

- A'lām al-muhaddithīn by Muhammad Abu Shahbah (d. 1403/1983). ${ }^{15}$

- A'yān al-shī'a by Muhsin al-Amīn (d. 1371/1952). ${ }^{16}$

- Al-Hāfíz Abu Nu'aym al-Ișfahānī: al-faqīh al-muḥaddith al-ṣūfi al-mu'arrih by Abd al-Hafīz al-Qaranī (d. 1434/2013). ${ }^{17}$

- Abu Nu'aym al-Ișfahā nī by Johannes Pedersen (d. 1977). ${ }^{18}$

- Fārūq Hamāda's edition of Kitā $b$ al-Ḍ u' afã ' by Abu Nu'aym al-Ișfahānī. ${ }^{19}$

- Jāmi' karamāt al-awliyā ’ by Yusuf al-Nabhānī (d. 1350/1932). ${ }^{20}$

- Muhammad al-Shāfiè's edition of al-Musnad al-mustakhraj 'alā Șahịḥ̣ Muslim by Abu Nu' aym al-Ișfahānī. ${ }^{21}$

- Sufi Apologia in the Guise of Biography: The Case of Abū Nu'aym alIs fahā n̄̄ 's Hilyat al-awliyā' wa-țabaqāt al-as fiyā 'by Meis Al-Kaisi. ${ }^{22}$

It should be noted that the information presented in the following text is primarily based on the sources which belong to the first two categories, 'Classical' and 'Post-Classical.' The 'Modern' sources are referred to only when and if they provide additional information.

This paper presents a concise biography of Abu Nu'aym al-Ișfahānī, which sheds light on his life, and accounts for all views and backgrounds, both positive and negative. All the available sources have been consulted to conclude what is in this study. The main objective was to examine the two opposing opinions of $\mathrm{Abu} \mathrm{Nu}$ aym

12 Muhammad Al-Ṣabbāgh, Abu Nu'aym, Hayātuhu Wa-Kitābuhu Al-Hilya, 2nd ed. (Dār al-I'tișām, 1978).

13 Christopher Melchert, “Abū Nu‘Aym's Sources for Hilyat Al-awliyā', Sufi and Traditionist," in Les Maîtres Soufis et Leurs Disciples Des IIIe-Ve Siècles de l'hégire (IXe-XIe), ed. G. Gobillot and J. Thibon (Damascus: Presses de 1'Ifpo, 2012), 145-59, https://doi.org/10.4000/books.ifpo.3078.

14 Khayr al-Dīn Al-Ziriklī, Al-A 'Tām (Cairo: al-Mu'allif, 1927).

15 Muhammad Abu Shahbah, A'lām Al-Muhaddithīn, 1962.

16 Muḥsin Al-Amīn, $A^{\prime} y a \bar{n}$ Al-Shī’a (Beirut: Dār al-Ta āruf li-l-Maṭba āt, 1986).

17 Abd al-Ḥafīz Al-Qaranī, Al-Hāfiz Abu Nu'aym Al-Iṣfahānī: Al-Faqīh Al-Muhaddith Al-Ṣūfì AlMu'arrikh (Cairo: al-Hay’a al-Mișriyya al-' Āmma li-l-Kitāb, 1987).

18 J. Pedersen, "Abū Nu'aym Al-Ișfahān̄̄," in Encyclopaedia of Islam, ed. P. Bearman et al., 2 ${ }^{\text {nd }}$ ed., 2012, https://doi.org/10.1163/1573-3912_islam_SIM_0239.

19 Abu Nu aym Al-Iṣfahānī, Kitāb Al-Ḍu 'afā', ed. Fārūq Hamāda (Casablanca: Dār al-Thaqāfa, 1984).

20 Yusuf Al-Nabhān̄̄, Jāmi` Karamāt Al-Awliyā' (Cairo: Dār al-Kutub al- 'Arabiyya al-Kubrā, 1911).

21 Abu Nu'aym Al-Ișfahānī, Al-Musnad Al-Mustakhraj 'alā Șaḥ̄ḥ Muslim, ed. Muhammad Al-Shāfie (Beirut: Dār al-Kutub al- 'Ilmiyya, 1996).

22 Meis Al-Kaisi, "Sufi Apologia in the Guise of Biography: The Case of Abū Nu 'aym Al-Ișfahānī’s Hiilyat Al-Awliyā' Wa-Ṭabaqāt Al-Așfiyā'," British Journal of Middle Eastern Studies 43, no. 1 (January 2, 2016): 115-34, https://doi.org/10.1080/13530194.2015.1075378. 
al-Ișfahānī, whom the majority accepted as an authority and the opposing minority rejected due to his favoritism of the $A s h$ 'an creed, Sufism, and also due to an assumed association with sectarianism. This paper unfolds everything that has come down to us in literature in this regard.

\section{B. The Life of Abu Nu'aym Al-Ișfahānī and his Status in Islamic Intellectual History}

Abu Nu aym al- Iṣfahānī, whose full name is Ahmad b. Abd Allah b. Ahmad b. Ishāa b. Musa b. Mihrān al-Mahrānī al-Ișfahānī (or al-Așbahānī) al-Ṣūfî ${ }^{23}$ al-Ahwal (squint-eyed), ${ }^{24}$ was born in Rajab $336 / \mathrm{Jan}-\mathrm{Feb} 948 .{ }^{25} \mathrm{He}$ is primarily remembered as a Shāfi'i jurist, a hadith transmitter, and as the author of many famous works, out of which Hilyat al-awliyā' 'wa-țabaqūt al-aṣfiyā ' is always mentioned. ${ }^{26}$

Abu Nu aym's father, Abd Allah b. Ahmad was one of Isfahan's fine scholars and narrators. Qaranī introduces him by saying: "He was a great scholar who narrated numerous Hadith." 27 Some classical scholars introduce Abu Nu'aym as the maternal grandson of Muhammad b. Yusuf al-Bannā' (n.d.), who was a well-known ascetic and Sufi scholar. ${ }^{28}$ However, Abu Nu'aym himself mentions in his Dhikr akhbār Ișbahān that his father, Abd Allah b. Ahmad b. Ishāq b. Musa b. Mihrān (231-365/846-976), was the grandson of Muhammad al-Bannā'. He says: "My father, may God have mercy on him, died in the month of Rajab in the year 365 and was buried next to his maternal grandfather Muhammad b. Yusuf al-Bannā' al-Șūfî." ${ }^{29}$ In addition, Abu Nu'aym mentions Muhammad al-Bannā' in the introduction to his Hilyat al-awliyā' wațabaqāt al-aṣ fiy $\bar{a}$ ' as his forerunner. ${ }^{30}$

23 Al-Dhahabī, Tadhkirat Al-Huffāz, III, 275; Al-Subkī, Țabaqāt Al-Shāfi 'iyya Al-Kubrāa, IV, 18; AlSuyūṭī, Tabaqāt Al-Huffāz, 423.

24 Al-Dhahabī, Tadhkirat Al-Huffāz, III, 275; Al-Suyūṭī, Tabaqāat Al-Huffāz, 423.

25 Al-Dhahabī, Tadhkirat Al-Huffāz, III, 275; Al-Sha arān̄̄, Al-Tabaqāt Al-Kubrāa, I, 56; Al-Subkī, Tabaqāt Al-Shāfi 'iyya Al-Kubrā, IV, 18; Al-Suyūțī, Tabaqāt Al-Huffāz, 423. reports year 336/948 as well but does not offer a specific month. Other sources report different birthdates. Ibn Khallikān, Wafayāt al-a'yān, I, 74, for instance, says that "according to some" Abu Nu'aym was born in 334/945, while Hamawī, K. Mu'jam al-buldān, I, 389 reports Rajab 330/March-Apr 942, and Amīn, A'yān al-shī'a, III, 6, reports Rajab 353/Jul-Aug 964.

26 For a study on the Hilya see Al-Kaisi, "Sufi Apologia in the Guise of Biography: The Case of Abu Nu'aym Al-Iṣfahān̄̄’s Hilyat Al-Awliyā' Wa-Ṭabaqāt Al-Așfiyā'.."

27 Al-Qaranī, Al-Häfiz Abu Nu'aym Al-Issfahānī: Al-Faqīh Al-Muhaddith Al-Süfĭ Al-Mu'arrikh, 49.

28 Al-Dhahabī, Tadhkirat Al-Huffāz, III, 275; Al-Subkī, Tabaqāt Al-Shāfi 'iyya Al-Kubrāa, IV, 18; AlSuyūțī, Tabaqāt Al-Huffāz, 423.

29 Abu Nu'aym Al-Ișfahān̄i, Dhikr Akhbār Ișfahān (Geschichte Iṣbahans), ed. Sven Dedering (Leiden: Brill, 1931), II, 93.

30 Al-Dhahabī, Tadhkirat Al-Huffāz, III, 275; Al-Subkī, Tabaqāt Al-Shāfíiyya Al-Kubrāa, IV, 18; AlSuyūṭī, Tabaqāt Al-Huffäz, 423.

30 Abu Nu'aim Al-Isfahani, Hilyat Al-Auliya Wa-Tabaqat Al-Asfiya, vol. II (Beirut: Dar al-Fikr li 1Tiba'a wa 1-Nasyr wa 1-Tawzi, 1996), I, 34. 
Abu Nu'aym's father played a great role in laying down the tracks for his son's education from the age of six. ${ }^{31} \mathrm{He}$ had him taught by important teachers, such as Khaythama b. Sulaymān al-Ațrābilsī, and Abu al-Abbas al-Așamm. ${ }^{32}$ Consequently, $\mathrm{Abu} \mathrm{Nu}$ aym had the unique opportunity to narrate exclusive anecdotes, which constituted the building blocks to his subsequent works. In Dhikr akhbār Ișbahān, Abu

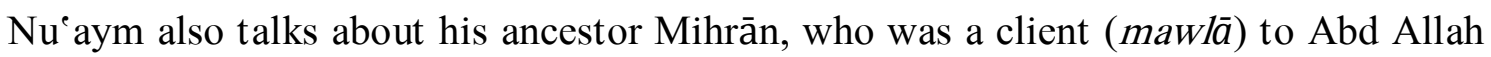
b. Mu'āwiya b. Abd Allah b. Ja'far b. Abī Țālib (d. 129/746-7), and the first of his kin to accept Islam. ${ }^{33}$

Abu Nu'aym was a Sunni Shäfí̄ scholar who followed the Ash $^{\prime}$ añ creed. $^{34}$ However, there are hypotheses suggesting that $\mathrm{Abu} \mathrm{Nu}$ aym was disposed towards Shiism on account of various factors. ${ }^{35}$ According to Qaranī, one of these factors relates to Abu Nu aym's ancestor Mihrān mentioned above. ${ }^{36}$ Qaranī emphasizes that a freedman follows the creed of his master and thus the attribution of Shiism to Abu

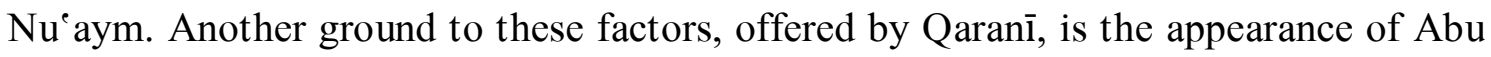
Nu'aym's biography in some works on the Shiites, such as $A^{\prime} y \bar{a} n$ al-shī'a by Muhsin al-Amīn, and Raw ḍāt al-jannāt by Mīrzā Muhammad Bāqir. However, the author of A'yān al-shī'a, Amīn himself, states that Abu Nu'aym was a Sunni scholar, (min 'ulamā' ahl al-sunna) who had written enormously on ahl al-bayt (family of the Prophet), which had mislead many to think that he was a Shiite. ${ }^{37}$ Amin's justification for the inclusion of the biography is based upon the mention of Abu Nu'aym's Shiite friends.

$\mathrm{Abu} \mathrm{Nu}^{\mathrm{e}}$ aym possessed a distinguished reputation and was praised by many famous scholars and historians, who had spoken of him in their writings and described him as a great Sufi and a famous traditionist. He was an authority on fiqh (jurisprudence) and țasawwuf (Sufism), and was proficient in memorization and accuracy. ${ }^{38}$ In Mizān al-i' tidāl fi naqd al-rijāl, Dhahabì reported that Abu Nu aym was one of the greatest scholars as well as a truthful traditionist, whose station of Imam was accepted by people unanimously. ${ }^{39}$ In his other work, Tadhkirat al-huffãz, alongside Suyūṭī in Tabaqāt al-ḥuffāz and 'Asqalānī in Lisān al-mīzān, Dhahabī

31 Al-Dhahabī, Tadhkirat Al-Huffāz, III, 275; Al-Suyūṭị, Tabaqāt Al-Huffāz, 423.

32 Al-Dhahabī, Tadhkirat Al-Huffāzz, III, 275; Al-Dhahabī, Al- 'Tbar F̄̄ Khabar Man Ghabar, III, 170; AlDhahabī, Siyar A 'lām Al-Nubalā', XVII, 454; Al-'Imād, Shadharāt Al-Dhahab F̄̄ Akhbār Man Dhahab, V, 149; Al-Subkī, Tabaqā̄t Al-Shāfi 'iyya Al-Kubrāa, IV, 18-19.

33 Al-Iṣfahānī, Dhikr Akhbār Ișfahān (Geschichte Iṣbahans), II, 93.

34 Al-Qaran̄i, Al-Hāfiz Abu Nu'aym Al-Ișfahānī: Al-Faqīh Al-Muhaddith Al-Süfì Al-Mu'arrikh, 73; AlȘabbāgh, Abu Nu aym, Hayātuhu Wa-Kitābuhu Al-Hilya, 14-15.

35 Al-Amīn, A'yān Al-Shī'a, III, 7; Al-Qaran̄̄, Al-Hāäiz Abu Nu'aym Al-Isfahānī: Al-Faqīh AlMuhaddith Al-Süfí Al-Mu'arrikh, 83.

36 Al-Qaranī, Al-Häfiz Abu Nu'aym Al-Issfahānī: Al-Faqīh Al-Muhaddith Al-Șüfì Al-Mu'arrikh, 83.

37 Al-Amīn, $A$ 'yān $A l$-Shì'a $a$ III, 7.

38 Al-Subkī, Țabaqāat Al-Shāfi 'iyya Al-Kubrā, IV, 18.

39 Al-Dhahab̄i, Mizān Al-I'tidāl Fī Naqd Al-Rijāl, I, 111.

Teosofia: Indonesian Journal of Islamic Mysticism, Vol. 10, No. 2, 2021 
presented $\mathrm{Abu} \mathrm{Nu}^{\mathrm{e}}$ aym as a great hăfiz and the traditionist of their time. ${ }^{40}$ Also, Ibn al-Najjār (d. 643/1245) considered Abu Nu'aym to be at the top of the traditionists and as one of the renowned religious figures (huwwa tāj al-muh addithīn wa-ahh ad a' làm al-dìn). ${ }^{41}$ Moreover, in Siyar a'lām al-nubalā', alongside Subkī in Tabaqāt alShāfí iyya al-kubrā, Dhahabī mentions that Ahmad b. Muhammad b. Mardawayh (n.d.) had once said that people used to seek $\mathrm{Abu} \mathrm{Nu}$ 'aym as he was the asnad (most reliable) and the ahfaz (most highly competent in knowing and memorizing hadith) muhaddith at his time, and that the huffä $z$ of the world used to gather around him. ${ }^{42}$ Also, al-Khatīb al-Baghdādī (d. 463/1071), one of Abu Nu'aym's many students, said that he had not seen anyone ahfaz than Abu Nu'aym al-Iṣfahānī and Abì Hāzim al$A^{'}$ raj (n.d.). ${ }^{43}$ Furthermore, in his famous book Wafayāt al-a'yān wa-anbā' abnā' alzamān, Ibn Khallikān wrote:

The celebrated hāfiz Abū Noaim (sic) Aḥmad Ibn 'Abd Allāh Ibn Aḥmad Ibn Ishāk Ibn Mūsā Ibn Mihrān al-Iṣbahānī (native of Ispahan), author of the Hilyat al-Awliyā', and one of the principal traditionalists, was a hāfiz of the highest authority: he had studied under men of the first merit, who themselves received from him useful information. ${ }^{44}$

Dhahabī and Subkī narrate that Hamza b. al-Abbas al- 'Ilawì (n.d.) confirmed that for fourteen years Abu Nu aym had been reckoned, by hadith scholars, to be the best hadith-authority. ${ }^{45}$ He continued by saying that the hadith scholars also mentioned that the Hilya, after its completion, was highly valued and was sold for four hundred dinars in Nishapur. Also, in Tabȳn kadhib al-muftañ̄, Ibn 'Asākir said that Abu Nu'aym had compiled famous works, such as the Hilya and many others involving hadith sciences. ${ }^{46}$ He proceeded by stating that $\mathrm{Abu} \mathrm{Nu}$ 'aym's reputation had reached distant lands and that people had benefited from his marvelous work. Moreover, on the authority of Abu Ṭāhir al-Silafī (d. 576/1180), who collected anecdotes on Abu Nưaym, Alī b. alMufaḍal (n.d.) said that the number of those who had transmitted hadith from Abu

40 Al-'Asqalānī, Lisān Al-Mīzān, I, 308f; Al-Dhahabī, Tadhkirat Al-Huffāz, III, 275; Al-Suyūṭī, Tabaqāt Al-Huffāz, 423. Ibn Khallikān explains that the "hăfiz (pl. huffāz) is the person who knows the Qur'ān by heart. However, this title is given more specifically to those doctors who have learned by heart the contents of the six great collections of Traditions, and who can cite the names of the persons by whom each tradition has been successively handed down, and who can point out those traditionists whose authority cannot be admitted without limitation and those who merit full confidence. The word hăfiz is sometimes made use of to designate a narrator of historical traditions." See Ibn Khallikān, Wafayāt AlA'yān (Cairo: Maṭba'at al-Bulāq, 1871), I, 57, footnote 1. Moreover, this title is given to those who have memorised 100 thousand hadith with their full chain of transmitters.

41 Al-Subkī, Tabaqāt Al-Shāfi 'iyya Al-Kubrā, IV, 21.

42 Al-Dhahabī, Siyar A 'lām Al-Nubalā', XVII, 459; Al-Subkī, Tabaqāt Al-Shāfi 'iyya Al-Kubrā, IV, 21.

43 Al-Dhahabī, Tadhkirat Al-Huffāz, III, 276.

44 Khallikān, Wafayāt Al-A yā̄n, I, 74.

45 Al-Dhahabī, Tadhkirat Al-Huffāz, III, 276; Al-Dhahab̄̄, Siyar A 'lām Al-Nubalā', XVII, 459; AlSubkī, Tabaqāt Al-Shāfi 'iyya Al-Kubrā, IV, 21.

46 'Asākir, Tabyīn Kadhib Al-Muftarī F̄̄-Ma Nusiba Ilā Al-Imām Ab̄̄ Al-Hasan Al-Ash'arī, 246. 
$\mathrm{Nu}$ aym was about eighty and that there had not been any work as estimable as the Hilya. $^{47}$

There is a number of factors that assisted $\mathrm{Abu} \mathrm{Nu}$ aym in achieving an eminent reputation as well as a significant status and made him a renowned figure in the hadith tradition. The very first and the most important factor that was to grant him the titles of al-imam al-jahl (honorable and great imam), al-hāfiz, and al-muhaddith, was his long and intensive journey in learning, which started with his father at the age of six and ceased at the age of ninety-four. He had learned from reputable scholars, traveled extensively seeking knowledge, and gained trust and respect from all his students. The consulted sources report a total of 46 different teachers and 70 students. Moreover, Abu Nu'aym's broad knowledge in the different fields, namely Hadith, Sufism, history,

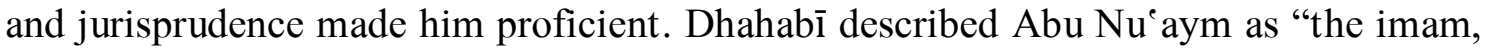

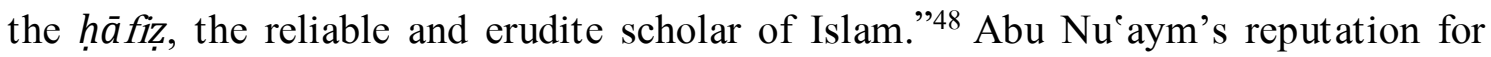
being a trustworthy source had emerged from his referral to reliable and continuous chains of hadith transmitters. This enabled his works to be greatly recognized and could be considered as yet another factor on the list. The many significant books he had written granted him the fame of an author of many works (șăhib al-tașānīf) and this was definitely another crucial factor of his success. The consulted sources report a total of 75 different works, some of which have survived and others only known to us as titles of lost works. In fact, Abu Nu'aym's works may be categorized into three categories; (1) those that have been published, (2) those available in manuscript form only, and (3) those that have been lost. The largest and most famous of all his works is a multivolume biographical encyclopedia named Hilyat al-awliyā' wa-țabaqāt alas fiyā' '. It includes 689 biographies on great figures of Islam, who have been known for their piety, asceticism, and great learning. Hilyat al-awliyā' has been published numerous times between 1932 and 2018 in both print and eBook formats in three different languages. Nonetheless, none of the existent editions, as far as I have examined, may be considered truly critical. Abu Nu'aym's second-largest work is Dhikr akhbār Ișbahān. It contains biographies of people who were related to Isfahan, mainly scholars, listed after a short history and topography of the town. This work also has been published several times.

$\mathrm{Abu} \mathrm{Nu}$ aym died in Isfahan on Monday $21^{\text {st }}$ of Muharram year 430/1038, and his grave is said, by Hamawī, to be in Mardabān. ${ }^{49}$ However, there have been many discrepancies about the exact month and day of his death. Suyūtī states that Abu $\mathrm{Nu}^{\mathrm{e}}$ aym died in the month of Muharram 430/Oct $1038 .{ }^{50}$ Others confirm that he died

47 'Asākir, Tabyīn Kadhib Al-Muftarī Fì-Ma Nusiba Ilā Al-Imām Abī Al-Hasan Al-Ash arī; Al-Dhahabī, Siyar A 'lām Al-Nubalā', XVII, 458.

48 Al-Dhahabī, Siyar A 'lām Al-Nubalā', XVII, 454.

49 Al-Hamawī, Mu'jam Al-Buldān, I, 398.

50 Al-Suyūṭ̂̄, Ṭabaqāt Al-Huffāz, 423. 
on Monday the $20^{\text {th }}$ of Muharram 430/22 $2^{\text {nd }}$ Oct $1038 .{ }^{51}$ Though Ibn Khallikān, alongside Ibn 'Asākir, claims the month of Șafar 430/Nov 1038 to be the date of Abu Nu'aym's death, he still states that "others placed his death on Monday $21^{\text {st }}$ of Muharram of that year." ${ }^{2}$ Nevertheless, Ibn 'Asākir also states that he had been told that $\mathrm{Abu} \mathrm{Nu}$ aym died at the age of 94 , on Monday $21^{\text {st }}$ of Muharram 430/23 ${ }^{\text {rd }}$ Oct 1038 , and was buried on the same day after the noon prayers. ${ }^{53}$ Ibn Kathirr, however, places Abu Nu'aym's death on the $28^{\text {th }}$ of Muharram $430 / 30^{\text {th }}$ Oct 1038 , whereas Ibn al-Jawzī reports it on the $12^{\text {th }}$ of Muharram $430 / 14^{\text {th }}$ Oct $1038 .{ }^{54}$

\section{Criticism against $\mathrm{Abu} \mathrm{Nu}$ aym}

The majority of scholars, in different centuries, have always spoken well of Abu $\mathrm{Nu}$ aym, and have always admired his works as well as accepted his station of Imam. Nevertheless, although $\mathrm{Abu} \mathrm{Nu}^{\circ} \mathrm{aym}$ is remembered as one of the principal traditionists, and as a hăfiz of the highest authority, we still find some scholars who have criticized him and his Hilya. It should be noted that there are two characteristics in Abu Nu'aym's personality that might have been the cause of some of the criticism directed towards him, namely Sufism and the Ash'an creed which are connected through bridges of harmony and sympathy. In his biography of Abu Nu'aym, Dhahabì cites Abu Ṭāhir al-Silafĩ saying:

Abu Nu'aym was rejected at that time due to his affiliation to his school of thought as there was an exaggerated fanaticism between the Hanābila and the Ash' ariyya that resulted in civil strife. ${ }^{55}$

The criticism of some scholars towards $\mathrm{Abu} \mathrm{Nu}$ aym was of different intensities as it was based on different grounds. The strife between the Hanäbila and the Ash ariyya caused sharp criticism of $\mathrm{Abu} \mathrm{Nu}$ aym by his fellow townsman, the Hanbali jurist, Abu Abd Allah Muhammad b. Isḥāq b. Yahya b. Manda, known as Ibn Manda (d. 395/1005), and led to physical attacks on him. Abu Nu'aym was even expelled from the mosque of Isfahan and was later exiled from the whole town. Fortunately, his absence from the town at that time had saved his life since, according to sources, the

51 Al-Dhahabī, Tadhkirat Al-Huffāz, III, 279; Al-Dhahabī, Siyar A 'lām Al-Nubalā', XVII, 462; AlSubkī, Tabaqāt Al-Shāfi 'iyya Al-Kubrā, IV, 22; Al-Hamawī, Mu'jam Al-Buldān, I, 398. However, this date cannot be correct since $20^{\text {th }}$ Muharram year $430 \mathrm{AH}$ was a Sunday.

52 'Asākir, Tabȳ̄n Kadhib Al-Muftarī F̄̄-Ma Nusiba Ilā Al-Imām Ab̄̄ Al-Hasan Al-Ash'arī, 246; Khallikān, Wafayāt Al-A yān, I, 74.

53 'Asākir, Tabyīn Kadhib Al-Muftarī F̄̄-Ma Nusiba Ilā Al-Imām Abī Al-Hasan Al-Ash arī, 246.

54 Al-Jawzī, Al-Muntazam F̄̄ Tawarīkh Al-Mulūk Wa-l-Umam, IX, 292; Kathīr, Al-Bidāya Wa-l-Nihāya, VI (11), 48-49.

55 Al-Dhahabī, Tadhkirat Al-Huffāz, III, 277; Al-Dhahabī, Siyar A 'ām Al-Nubalā', XVII, 459. On Hanbalites, see H. Laoust, "Hanābila," in Encyclopaedia of Islam, ed. P. Bearman et al., $2^{\text {nd }}$ ed. (Leiden: Brill, 2012), https://doi.org/10.1163/1573-3912_islam_COM_0263. See also, Mohd Hameedullah Khan, The Schools of Islamic Jurisprudence: A Comparative Study, $2^{\text {nd }}$ ed. (India: Kitab Bhavan, 1997), 110-20. 
Turkish Sultan Sebük Tigin conquered Isfahan and massacred the people assembled in the mosque at the Friday service. ${ }^{56}$ This is reckoned as one of $\mathrm{Abu} \mathrm{Nu}^{\text {e aym's graces }}$ $($ karāmāt $) .{ }^{57}$

The conflict between $\mathrm{Abu} \mathrm{Nu}$ aym and Ibn Manda is mostly known since any mention of either one of them would bring it clearly to the surface. In his biography on Ibn Manda, Dhahabī says: "Ibn Manda deprecated and accused the hāfiz Abu Nu'aym and repudiated him regarding his impugnment [of narrators] due to the enmity between them." ${ }^{58}$ In his biography on Abu Nu'aym, he says: "Ibn Manda comments regarding Abu Nu'aym are shocking, and I do not like to make mention of them; similarly, I do not accept either of their statements about the other." 59 These statements show that both Abu Nu'aym and Ibn Manda openly displayed their disrespect towards each other. Further, in Abu Nu'aym's biography, Dhahabī explains:

The statements of contemporaries concerning each other aren't to be taken into consideration, especially if it appears to be based on enmity, creed, or envy. No one is saved from this except those whom God has protected; I know of no period in history in which people avoided this except for the prophets and the righteous. ${ }^{60}$

Then, he pins it down further to al-balā' al-ladhì bayn al-rajulayn huwwa 1$i^{\prime} t i q \bar{a} d .^{61}$ This clearly explains the impetus behind the dispute, namely creedal matters.

However, the conflict between the jurists and the Sufis, which arose during the $3^{\text {rd }} / 9^{\text {th }}$ century, might have been another reason behind the dispute between Abu Nu aym and Ibn Manda. This conflict originated with the blossoming of Sufism, which shifted from a state of worship and asceticism to a state of theoretical Sufism. Hence, different Sufi schools emerged with new methods revealed, and each school had its own students and teachers. Sufis had deemed themselves as providentially selected celestial individuals, as saints and God's Friends (awliyā'), whose spiritual accomplishments were akin to the experience of the Prophets. They also laid claim to an unconditional relationship of mutual love between themselves and God. This provoked the hostilities of the scholars of law and religion, namely the 'ulama' '.

This relationship of mutual love between the mystic and God seemed to have been the main point of controversy, in particular when such a claim was made public. Once the feeling of a visionary experience of God or a symbolically-mediated

56 Al-Dhahabī, Tadhkirat Al-Huffāz, III, 277f; Al-Dhahabī, Siyar A 'ām Al-Nubalā', XVII, 460; AlNabhān̄̄, Jāmi' Karamāt Al-Awliyā', I, 293; Al-Subkī, Tabaqāt Al-Shāfi 'iyya Al-Kubrā, IV, 21f. Khan Sebük Tigin is the founder of the Ghaznavid Empire, which was a state in the region of today's Afghanistan that existed from 963 to 1187 AD.

57 Al-Dhahabī, Siyar A 'lām Al-Nubalā', XVII, 460; Al-Subkī, Tabaqāt Al-Shāfi 'iyya Al-Kubrā, IV, 22.

58 Al-Dhahabī, Tadhkirat Al-Huffāz, III, 479.

59 Al-Dhahabī, Mizān Al-I'tidāl F̄̄ Naqd Al-Rijāl, I, 111.

60 Al-Dhahabī, Mizān Al-I'tidāl Fī Naqd Al-Rijāl.

61 Al-Dhahabī, Tadhkirat Al-Huffāz, III, 479. 
encounter became a public malicious scandal, Sufis were maltreated by society and prosecuted by the government. Subsequent to public exposure, Sufi doctrines were assaulted and undermined by the scholars of law and religion and eventually labeled as heretical. ${ }^{62}$

Another form of sharp criticism against $\mathrm{Abu} \mathrm{Nu}$ aym, over a century after his death, was by the Hanbali scholar Ibn al-Jawzì. From his short biography on Abu $\mathrm{Nu}$ aym, which he provides in Al-Muntazam fi tawan̄kh al-mulük wa-l-umam, and from his other references to $\mathrm{Abu} \mathrm{Nu}^{\text {eaym}}$, one can sense the dislike Ibn al-Jawzì had towards him. ${ }^{63} \mathrm{He}$ presents $\mathrm{Abu} \mathrm{Nu}^{\mathrm{e}}$ aym as a person who learned and compiled tremendously (sami'a al-kathīr wa-șannafa al-kathìr) but thereafter stresses Abu $\mathrm{Nu}$ aym's propensity towards the Ash ariyya saying: wa-kāna yamīl ilā madhhab alash ariyya maylan kathïran. He proceeds by reporting a critique stated by Abu Bakr Ahmad b. Ali b. Thābit: "Abū Nu'aym used to mix up the hadith he heard directly with those he was given permission to narrate without distinguishing one from the other,"64 followed by al-Nakhshabī's critique: "Even though Abu Nu'aym did not hear the whole of al-Hārith's musnad from Abī Bakr b. Khilād, he still narrated all of it,"65 avoiding any proposals of defense to mitigate the attacks. However, Dhahabi and Subkī present evidence to defend Abu Nu'aym and exculpate him from all suspicion imputed to him. ${ }^{66}$ For instance, we find a critical statement by al-Khațīb al-Baghdādī on Abu Nu'aym in which he says:

I have seen Abu Nu'aym being careless regarding several things, such as indicating direct narration of hadith for which he was only given [written] authorization to transmit without clarifying it as such. ${ }^{67}$

Dhahabì retaliates and renders assertions to the contrary in all his consulted works. In Tadhkirat al-huffäz, he admits that such accusations could be applicable but

62 For more details on the subject see Gerhard Böwering, "Early Sufism between Persecution and Heresy," in Islamic Mysticism Contested: Thirteen Centuries of Controversies and Polemics, ed. F. de Jong and B. Radke (Leiden: Brill, 1999), esp. 53-59. See also Al-Qaran̄̄, Al-Hāafiz Abu Nu'aym AlIssfahānī: Al-Faqīh Al-Muhaddith Al-Ṣufì Al-Mu'arrikh, 73-77.

63 Al-Jawzī, Al-Muntaẓam F̄̄ Tawarīkh Al-Mulūk Wa-l-Umam, IX, 292; Ibn Al-Jawzī, Șifat Al-Ṣafwa, ed. M. Fakhūrī (Aleppo: Dār al-Waèy, 1973), I, 20-31; Ibn Al-Jawzī, Talbīs Iblīs, ed. M. M. alDimashqī et Al., $2^{\text {nd }}$ ed. (Beirut: Dār al-Ra'id al-'Arabī, 1949), 165.

64 Al-Jawzī, Al-Muntazam F̄̄ Tawarīkh Al-Mulūk Wa-l-Umam, IX, 292.

65 Al-Jawzī, Al-Muntazam F̄̄ Tawarīkh Al-Mulūk Wa-l-Umam.

66 For more details on what was said against these utterances and some others, see Al-Dhahabī, Tadhkirat Al-Huffāz, III, 278; Al-Dhahab̄̄, Siyar A 'lām Al-Nubalā', XVII, 460-62; Al-Subkī, Țabaqāt Al-Shäfi iyya Al-Kubrā, IV, 22-25. It should also be mentioned that right at the beginning of his biography on Abū Nu'aym, Dhahabī in Mizān al-i'tidāl, I, 111, stated that things have been said about $\mathrm{Abū} \mathrm{Nu}$ aym without evidence 'takallama fìhi bala hujja'.

${ }^{67}$ Cited in Al-Subkī, Tabaqāt Al-Shāfi 'iyya Al-Kubrā, IV, 23; Al-Dhahab̄̄, Tadhkirat Al-Huffāz, III, 278; Al-Dhahabī, Mizān Al-I'tidāl Fō Naqd Al-Rijāl, I, 111; Al-Dhahabī, Siyar A 'ām Al-Nubalā', XVII, 460. 
only in a few cases. ${ }^{68} \mathrm{He}$ then emphasizes that $\mathrm{Abu} \mathrm{Nu}^{\text {e }}$ aym was careful in selecting the appropriate terminology when transmitting a hadith and offers clarifying examples. In Siyar a'lām al-nubalā' Dhahabì argues: "Indicating direct narration when transmitting a hadith via authorization only is a well-known position, which was commonly practiced by the traditionists of Andalusia, where it became widespread." 69 Hence, Dhahabì bases his defense upon the disagreement that exists between the scholars on ijäza, emphasizing that this was the madhhab (school of jurisprudence) that $\mathrm{Abu} \mathrm{Nu}$ aym and many others followed. At the end he comments:

Thus, whatever al-Khațîb imagined and presumed is invalid and Abu

Nu'aym is not to be accused; on the contrary, he is trustworthy and a scholar who is erudite in this discipline. ${ }^{70}$

Subkī, however, dismisses Khațīb's statement, mentioned above, by saying: "It is not proven that al-Khatīib said this and as such, cannot be considered a vilification." 71 Then he says: "Using the phrase akhbaranā when referring to a tradition received via [written] authorization is a matter of dispute," which complies with the deduced statement by Dhahabī. ${ }^{72}$

It is noteworthy that, although Dhahabī defends and disagrees with what has been reported about $\mathrm{Abu} \mathrm{Nu}$ aym, he still censures the disrespect and the spleen $\mathrm{Abu}$ $\mathrm{Nu}$ aym had shown in his writings against Ibn Manda. He then continues to criticize both, Abu Nu aym and Ibn Manda by saying: "Both of them are acceptable to me; neither of them is guilty of anything other than narrating fabricated traditions without declaring them as such." 73 I beg to disagree with Dhahabì on this matter as narrating a fabricated hadith without clarifying is by no means acceptable and whoever is guilty of such actions cannot be called a trustworthy transmitter. The Prophet Muhammad is reported to have said: "He who tells a lie on me intentionally, let him take his seat in the Hellfire." 74

If we go back to Ibn al-Jawzī, we would observe, once again, criticism of Abu Nu aym and the Hilya in Talbīs Ib/is. ${ }^{75}$ There, he claims that Abu Nu'aym mentioned in the Hilya disowned and disgraceful affairs about Sufism and that he rebelliously

68 Al-Dhahabī, Tadhkirat Al-Huffāz, III, 278.

69 Al-Dhahabī, Siyar A 'lām Al-Nubalā', XVII, 461. Nevertheless, it should be mentioned that in Mizān al-i 'tidāl, I, 111, Dahabī argued against saying "akhbaranā" without "ijāzatan" by stating that "this was an opinion that Abū Nu'aym, as well as others, held whereas in fact it was a form of deception."

70 Al-Dhahabī, Siyar A 'lām Al-Nubalā'.

71 Al-Subkī, Țabaqāt Al-Shāfi 'iyya Al-Kubrā, IV, 24.

72 Al-Subkī, Tabaqāt Al-Shāfi ìya Al-Kubrā.

73 Al-Dhahabī, Mizān Al-I'tidāl F̄̄ Naqd Al-Rijāl, I, 111.

74 Muhammad Bukhārī, Șaḥ̄ḥ Bukhārī (Beirut: Dār Iḥyā' al-Turāth al- 'Arabī, 2001), no. 107.

75 Al-Jawzī, Talbīs Iblīs, 165. 
included among the Sufis Abu Bakr, Umar, Uthman, Ali, and the superiors of the Companions, and narrated the unthinkable about them. ${ }^{76}$

Moreover, in Ibn al-Jawzī's Sifat al-șafwa we find more substantial criticism of Abu Nu'aym and the Hilya, which discusses thirteen points in the sequence presented below: ${ }^{77}$

1. Ibn al-Jawzī argues that the main intent of the Hilya is to offer followers a clearer and more defined track of Sufism by providing reports on those devout and pious individuals that cover different aspects of their morals and positions. ${ }^{78} \mathrm{He}$ says that in some cases the biographies divert from the main aim of the work and report related materials only with nothing on the subject himself. For instance, the biography of Ja far b. Sulaymān al-Duba ${ }^{e} \overline{1}$ (d. 178/794) is mainly composed of his reports on Mālik b. Dīnār (d. 131/749), rather than information about Ja far himself.

2. Ibn al-Jawzì censures the topics of the materials presented in the biographies. He points out that on some occasions $\mathrm{Abu} \mathrm{Nu}$ aym was not careful in choosing the appropriate information that would be congruent with the orientation of the work. For example, in the case of Mujāhid b. Jabr, a Successor and a mufassir from Mecca (d. 104/722), Abu Nu'aym filled his biography with parts of his tafsitr (exegeses) of the Quran.

3. Another crucial point Ibn al-Ğawzī criticizes is the repetition of material in the inter-related biographies. For instance, sayings of Hasan al-Bașri, which were reported in his biography, were repeated in his friends' biographies. ${ }^{79}$

4. Long Hadith transmissions within one biography, is another point that Ibn al-Jawzi debates. He says that such long transmissions could result in deviation from the main characteristics of the subject. He also remarks that the Hadith does not have a common theme and that they discuss topics that are not in harmony with asceticism, the subject of the work from his point of view. ${ }^{80}$

5. Ibn al-Jawzī says that $\mathrm{Abu} \mathrm{Nu}$ 'aym included many doubtful and non-authentic hadith for the sake of lengthening his work as well as passing on some of his tales. $\mathrm{He}$ accuses $\mathrm{Abu} \mathrm{Nu}$ aym of obscuring facts that could consequently mislead people.

76 Al-Jawzī, Talbīs Iblīs.

77 Al-Jawzī, Sifat Al-Ṣafwa, I, 20-31.Ibn al-Jawzī, Șifat al-șafwa, I, 20-31.

78 See Al-Kaisi, "Sufi Apologia in the Guise of Biography: The Case of Abū Nu'aym Al-Ișfahānī’s Ḥilyat Al-Awliyā' Wa-Ṭabaqāt Al-Așfiyā'.” for an analysis of and a discussion about the main intent of the Hilya.

79 For a theory of multiple authorship, which explains the inconsistencies in the Hilya, see Jawid Mojaddedi, The Biographical Tradition in Sufism: The Tabaqāt Genre from Al-Sulamī to Jāmī (Richmond, Surrey: Curzon Press, 2001), chap. 2. See also Al-Kaisi, "Sufi Apologia in the Guise of Biography: The Case of Abū Nu'aym Al-Ișfahānī’s Ḥilyat Al-Awliyā’ Wa-Ṭabaqāt Al-Aṣfiyā’.”

80 I agree with Ibn al-Jawzī on the fact that many times the Hadith transmission discusses topics which are not in harmony with the biography's theme not to mention the remainder of the work, the content of which is mainly ascetic. 
6. Ibn al-Jawzī criticizes Abu Nu'aym for using rhymed prose that almost does not lead to a comprehensible meaning or purpose.

7. Another point in Ibn al-Jawzì's critique is attributing Sufism to individuals who are usually not identified as Sufis, for instance, Abu Bakr, Uthman, and alShāfi ì ${ }^{81}$

8. Ibn al-Jawzì contends Abu Nưaym's unnecessary lengthening of meaningless narration, which does not serve the main subject.

9. Abu Nu'aym attributed some inappropriate, irrelevant behavior and conduct to Sufism. Ibn al-Jawzī explains that such quotations could pose jeopardy to those novices who still lack the appropriate knowledge to distinguish between acceptable and unacceptable conduct.

10. Ibn al-Jawzī argues that $\mathrm{Abu} \mathrm{Nu}$ aym did not adhere to any criteria in organizing his work and consequently confuses the reader. ${ }^{82}$

11. Ibn al-Jawzì debates that $\mathrm{Abu} \mathrm{Nu}$ aym failed to provide a biography on the most superior ascetic, namely the Prophet Muhammad.

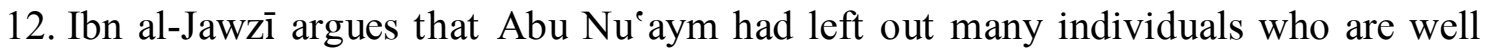
known for their piety and exertion. ${ }^{83}$

13. Finally, Ibn al-Jawzì debates that Sufi women had only a minute portion of the Hilya which he considers disadvantageous since male ascetics could use such sections to correct their own conduct.

\section{Conclusion}

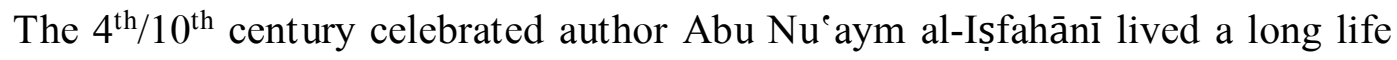
of 90 years during which he studied under a number of teachers, taught many students, and wrote numerous works. Apart from those works that seem to have been lost, many survived in manuscript form and received attention by modern scholarship, the result of which is the availability of many of his works in print today. The most significant of Abu Nu'aym's works is, with no doubt, the multivolume Hilyat al-awliyā' wa-țabaqāt al-așfiya ', which is available in both print and eBook formats as well as in abbreviated versions and short translations of selected extracts. His second-largest work, which has also been published, is Dhikr akhbār Iṣbahān, containing biographies of Isfahani scholars.

81 See Al-Kaisi, "Sufi Apologia in the Guise of Biography: The Case of Abū Nu 'aym Al-Ișfahānī’s Hilyat Al-Awliyā' Wa-Ṭabaqāt Al-Aṣfiyā̄'.” For an analysis and comments on this particular issue.

82 For a discussion on the usage of a number of competing organisational principles in the arrangement of the Hilya, see Mojaddedi, The Biographical Tradition in Sufism, which suggest that they may not have been applied by a single author and support his theory of multiple authorship. However, it should be noted that the overall scheme of the Hilya is chronological and the material is arranged according to tabaqāt (generations). See Al-Kaisi, "Sufi Apologia."

83 See Al-Kaisi, "Sufi Apologia," for an analysis and comments on this particular issue.

Teosofia: Indonesian Journal of Islamic Mysticism, Vol. 10, No. 2, 2021 
Abu Nu'aym is known for his distinguished reputation as a great Sufi, famous traditionist, an authority on fiqh, and a great hă fiz. Muslim scholarship has generally accepted $\mathrm{Abu} \mathrm{Nu}$ eaym and, in fact, celebrated his status as a scholar. Nonetheless, as much fame and renowned reputation had $\mathrm{Abu} \mathrm{Nu}$ aym gained as much criticism was given by those who saw him not worthy of the reputable status he had won. The criticism against $\mathrm{Abu} \mathrm{Nu}$ aym was based on different grounds. Some scholars seem to have had some personal disagreements with Abu Nu'aym, while others questioned his credibility in reporting Hadith, and others have accused him of misrepresenting Sufism. Abu Nu'aym al-Ișfahānī is certainly not unique in this respect as it stands to reason that no one would be accepted unanimously by all. It is, however, of great significance to recognize that which has been said both in his favor as well as against him. This paper has outlined all the available opinions by using a critical approach inclusive of a detailed analysis of what has been mentioned about $\mathrm{Abu} \mathrm{Nu}$ aym in both classical and modern literature.

\section{Bibliography}

'Asākir, Ali ibn. Tabyīn Kadhib Al-Muftarī Fì-Ma Nusiba Ilā Al-Imām Ab̄̄ Al-Hasan Al-Ash 'arī. Damascus: Matba ${ }^{\circ}$ at al-Tawthīq, 1928.

Al-'Asqalān̄̄, Ibn Hajar. Lisān Al-Mīzān. Edited by Adil Abd al-Mawjūd and Ali Mu awwaḍ. Beirut: Dār al-Kutub al- 'Ilmiyya, 1996.

Al-' Imād, Abd al-Hayy Ibn. Shadharāt Al-Dhahab Fī Akhbār Man Dhahab. Edited by Mahmud Al-Arna'ūt. Damascus: Dār Ibn Kathīr, n.d.

Al-Amīn, Muḥsin. A yō̄n Al-Sh̄̄'a. Beirut: Dār al-Ta āruf li-1-Maṭba āt, 1986.

Al-Dhahabī, Muhammad. Al-'Ibar F̄̄ Khabar Man Ghabar. Edited by Fu'ād Sayyid. Kuwait: al-Turāth al- 'Arabī, 1960.

- Mizān Al-I'tidāl F̄̄ Naqd Al-Rijāl. Edited by Ali Al-Bajawī. Cairo: Dār Ihyyā’ al-Kutub al-'Arabiyya, 1963.

_. Siyar A 'tām Al-Nubalā'. Beirut: Mu’assassat al-Risāla, 1981.

Tadhkirat Al-Huffāz. 2nd ed. Hyderabad: Dā'irat al-Ma'ārif al-Nizāāmiyya, 1915.

Al-Ḥamawī, Yāqūt. Mu 'jam Al-Buldān. Edited by Ferdinand Wüstenfeld. Leipzig: F. A. Brockhause, 1866.

Al-Isfahani, Abu Nu'aim. Hilyat Al-Auliya Wa-Tabaqat Al-Asfiya. Vol. II. Beirut: Dar al-Fikr li 1-Tiba'a wa 1-Nasyr wa 1-Tawzi, 1996. 
Al-Ișfahān̄̄, Abu Nu'aym. Al-Musnad Al-Mustakhraj alā Șaḥ̄h Muslim. Edited by Muhammad Al-Shāfi ${ }^{`}$. Beirut: Dār al-Kutub al-'Ilmiyya, 1996.

—. Dhikr Akhbār Ișfahān (Geschichte Ișbahans). Edited by Sven Dedering. Leiden: Brill, 1931.

Kitāb Al-Ḍu'afā'. Edited by Fārūq Ḥamāda. Casablanca: Dār al-Thaqāfa, 1984.

Al-Jawzī, Abd al-Rahman Ibn. Al-Muntazam F̄̄ Tawarīkh Al-Mulūk Wa-l-Umam. Beirut: Dār al-Fikr, 1995.

Al-Jawzī, Ibn. Șifat Al-Șafwa. Edited by M. Fakhūrī. Aleppo: Dār al-Wa y, 1973.

Talbīs Iblīs. Edited by M. M. al-Dimashqī et Al. 2nd ed. Beirut: Dār al-Ra'id al- ${ }^{-A}$ arabī, 1949.

Al-Kaisi, Meis. "Sufi Apologia in the Guise of Biography: The Case of Abū Nu'aym Al-Ișfahānī’s Hilyat Al-Awliyā' Wa-Ṭabaqāt Al-Aṣfiyā',." British Journal of Middle Eastern Studies 43, no. 1 (January 2, 2016): 115-34. https://doi.org/10.1080/13530194.2015.1075378.

Al-Nabhān̄̄, Yusuf. Jāmi` Karamāt Al-Awliyā'. Cairo: Dār al-Kutub al-'Arabiyya alKubrā, 1911.

Al-Qaranī, Abd al-Ḥafīz. Al-Häfiz Abu Nu'aym Al-Ișfahānī: Al-Faqīh Al-Muhaddith AlSüfì Al-Mu'arrikh. Cairo: al-Hay’a al-Mișriyya al- 'Āmma li-l-Kitāb, 1987.

Al-Șabbāgh, Muhammad. Abu Nu'aym, Hayātuhu Wa-Kitābuhu Al-Hilya. 2nd ed. Dār al-I 'ișām, 1978.

Al-Sha'arān̄̄, Abd al-Wahhāb. Al-Ṭabaqāt Al-Kubrā. Cairo: Maktabat wa-Mațba at Muhammad Ali Ṣubayḥ wa-Awlādih, 1897.

Al-Subkī, Abd al-Wahhāb. Tabaqāt Al-Shāfi 'iyya Al-Kubrā. Edited by Mahmud AlṬanahị and Abd al-Fattah Al-Ḥulw. Cairo: al-Ḥalabī, 1964.

Al-Suyūțī, Jalāl al-Dīn. Tabaqāt Al-Huffāz. Edited by Ali Umar. Cairo: Maktabat Wahba, 1973.

Al-Ziriklī, Khayr al-Dīn. Al-A 'Tām. Cairo: al-Mu'allif, 1927.

Böwering, Gerhard. "Early Sufism between Persecution and Heresy." In Islamic Mysticism Contested: Thirteen Centuries of Controversies and Polemics, edited by F. de Jong and B. Radke. Leiden: Brill, 1999.

Bukhārī, Muhammad. Șaḥ̄ḥ Bukhārī. Beirut: Dār Iḥyā’ al-Turāth al- 'Arabī, 2001.

Kathīr, Ismail Ibn. Al-Bidāya Wa-l-Nihāya. 3rd ed. Beirut: Dār al-Kutub al-'Ilmiyya, 1986.

Khallikān, Ahmad Ibn. Wafayāt Al-A yān: Biographies of Illustrious Men. Edited by Iḥsān Abbas. Beirut: Dār al-Thaqāfa, 1968. 
Wafayāt Al-A yān: Ibn Khallikan's Biographical Dictionary. Translated by Bn Mac Guckin de Slane. Paris: Benjamin Dupart, 1842.

Khallikān, Ibn. Wafayāt Al-A yā̄n. Cairo: Maṭba'at al-Bulāq, 1871.

Khan, Mohd Hameedullah. The Schools of Islamic Jurisprudence: A Comparative Study. 2nd ed. India: Kitab Bhavan, 1997.

Laoust, H. "Hanābila." In Encyclopaedia of Islam, edited by P. Bearman, Th. Bianquis, C.E. Bosworth, E. van Donzel, and W.P. Heinrichs, 2nd ed. Leiden: Brill, 2012. https://doi.org/10.1163/1573-3912_islam_COM_0263.

Melchert, Christopher. "Abū Nu'Aym's Sources for Hilyat Al-awliyā', Sufi and Traditionist." In Les Maîtres Soufis et Leurs Disciples Des IIIe-Ve Siècles de l'hégire (IXe-XIe), edited by G. Gobillot and J. Thibon, 145-59. Damascus: Presses de l'Ifpo, 2012. https://doi.org/10.4000/books.ifpo.3078.

Mojaddedi, Jawid. The Biographical Tradition in Sufism: The Tabaqāt Genre from AlSulamī to Jāmī. Richmond, Surrey: Curzon Press, 2001.

Pedersen, J. "Abū Nu'aym Al-Iṣfahānī." In Encyclopaedia of Islam, edited by P. Bearman, Th. Bianquis, C.E. Bosworth, E. van Donzel, and W.P. Heinrichs, 2nd ed., 2012. https://doi.org/10.1163/1573-3912_islam_SIM_0239.

Shahbah, Muhammad Abu. A'Tām Al-Muhaddithīn, 1962. 